\title{
PEDAGOGY
}

\section{Formation of the behavioral component of social experience in late adolescents under conditions of extracurricular educational activity}

\author{
T. Yu. Atroshenko \\ Bohdan Khmelnytsky Melitopol State Pedagogical University, Melitopol, Ukraine \\ Corresponding author. E-mail: tania.skadi@gmail.com
}

Paper received 24.10.19; Accepted for publication 09.11.19.

\section{https://doi.org/10.31174/SEND-PP2019-209VII86-01}

Abstract. The article substantiates the importance of forming the behavioral component of social experience in late adolescents. The author has analyzed the results of the diagnostics applied to define the level of late adolescents' social experience by the activity criterion. The research determines the most appropriate organizational forms of extracurricular educational activity with students in late adolescence which are used to form the behavioral component of their social experience. The characteristics of late adolescents which should be developed with the efforts of the teaching staff have been defined.

Keywords: social experience, behavioral component, late adolescents, extracurricular educational activity, socially acceptable behaviour.

Introduction. The cross-cutting task of the school educational activity is to make students assimilate the patterns of behavior, values, and ways of thinking that are integrated in their social experience. Under the conditions of personality structures transformation, which is characteristic of late adolescents, the students' ability to master the ways of socially acceptable behaviour deserves special attention. Extracurricular educational activity becomes the very environment that provides the teacher with the opportunity to develop the student's ability to act in accordance with the norms acceptable in society, to adopt existing patterns of behaviour, to participate in the team work, to show skills of self-regulation and self-control.

A brief overview of publications on the topic. L. Safronova, I. Starodubtseva, N. Ustinova and other scholars devoted their research to the formation of adolescents' social experience. Teachers S. Arkhypova and O. Arkhypov analyzed the system of diverse sociocultural activities in modern school as a basis for the development of social, socio-cultural and moral experience. D. Alfimov considers the students' acquisition of social experience through the development of leadership qualities at all ages in modern general education school. Researchers such as M. Babkina, A. Vysotska, S. Zakharov, I. Palasevych, L. Yakubova studied the formation of the adolescent personality through extracurricular educational activity.

The purpose of the article is to identify the forms of extracurricular educational activity favourable for the formation of the behavioral component of late adolescents' social experience.

Materials and methods. In order to determine the forms of extracurricular educational activity necessary for the formation of the behavioral component of late adolescents' social experience, the analysis of research works on this problem was carried out, the level of students' social experience was studied by activity criterion, with the help of questionnaires.

Results and their discussion. The process of socialization in adolescence reveals the child's striving for selfassertion in the social environment. That is why, as noted by $\mathrm{M}$. Babkina, it is necessary to help teenagers focus on social assertion in the process of learning and educational activities where they acquire certain knowledge and norms of social behavior [3, p. 7]. Providing specially organized activity on formation of social experience in late adolescents helps arouse their desire and interest to acquire knowledge on relationships with other people in society, to use this knowledge in social practice, which, in turn, increases the efficiency of the educational process, the successful formation of a positive social experience.

The child as a social being is characterized by certain manifestations of his/her position in society in general and in the school environment in particular. All of them are reflected in his/her behaviour. However, the child sometimes lacks the awareness of how his/her social knowledge and attitudes should be realized in his or her practical activity, which proves the insufficient formation of the behavioral component of social experience.

According to the research by T. Bilan [4, p. 204] and L. Safronova [7, p. 215], it can be determined that the behavioral component of social experience ("activity" component according to T. Bilan, and "practical activity" component according to L. Safronova) means that the late adolescents should use socially acceptable norms, rules, and values both in their behaviour and interaction with others, they should also demonstrate willingness to participate in various activities, as well as the ability to make decisions, and plan their team work.

Researchers use a number of criteria to study the level of social experience formation. Among them there is the activity criterion which is applied to study the behavioral component. The study of the social experience formation in late adolescents by activity criterion was carried out by means of the author's questionnaire, diagnostics methods which study the mastery level of socially acceptable activities (modified R. B. Cattel 16PF test, scales of "low normality of behaviour - high normality of behaviour" and "low self-control" - "high self-control") and diagnostics methods which study organizational inclinations (modified method of Communication and Organizational Inclinations-2). The study involved 168 students in their Year 7-9 of school.

Diagnostics results indicated a very small number of 
students with a high level of social experience formation by activity criterion $-10.7 \%$. The overwhelming majority of those surveyed has an average level (67.3\%). $22 \%$ of students have a low level.

Considering the answers of late adolescents on certain questions of the questionnaires, $95 \%$ of the respondents believe that people should, more than now, adhere to moral standards. It indicates that students are aware of the meaning of the norms, but it is not substantiated by anything, since, as other answers show, they do not want to observe the norms and organization in everyday life. For example, only $19 \%$ of adolescents believe that any work should be done thoroughly; 68\% cannot call themselves careful and practical; $43 \%$ think that the efforts made for planning are not worth it.

Students' neglecting socio-cultural demands negatively affects their adaptation to the social environment, orientation in the living space. In addition, adherence to ethical standards and certain behavioral standards ensures organization and order in society. Instead, 39\% of late adolescents think that a culture of behavior, good manners are not appreciated right now, so they are not really needed, $43 \%$ are willing to do what they want, even if others don't like it, and $32 \%$ consider that adherence to social norms limits their individuality. All this indicates a low moral awareness of late adolescents, in which moral knowledge is not supported by awareness of the morality importance. The late adolescent still does not understand the importance of the social moral consciousness formed during the historical development of humanity and, sometimes, perceives it as a relic of the past.

The same problems are manifested in the school life: $28 \%$ of students violate the rules of conduct at school, and $43 \%$ of respondents said that if the way they behaved at a lesson would not influence the teacher's assessment, they would most likely behave worse. That is, the regulator of these students' behavior is not an internal moral standard, but an external stimulus in the form of a mark for the subject. They do not understand why it is necessary to follow the norm, so they have no motive to do it. Therefore, it is required that the late adolescent should develop behavioral self-regulation in order to transform the internal characteristics of the personality and their external manifestations in the necessary direction.

Considering the level of students' involvement in socially useful activities, it was found out that $78 \%$ of the respondents want to participate in public events for the benefit of the community, but only $47 \%$ take part in community activities at school, $22 \%$ willingly involve in arranging social events, $30 \%$ of respondents do not like to take part in any community activities. Students are aware that such activities are beneficial to the community, but they are unwilling to join those ones who are involved. In some late adolescents, such attitude is associated with a lack of sense of duty, responsibility, team spirit, and in others - with the inability to embody their ideas into certain activities.

Low involvement in socially useful activities and low social activity are also explained by the lack of initiative among students: $27 \%$ are reluctant to arrange different events for their friends, $31 \%$ do not like to invent or arrange different games and entertainment with their friends, $37 \%$ rarely or never show the initiative to address the issues affecting the interests of their friends. This situation is characteristic of an immature group that is not yet capable of becoming the basis on which the child's striving for activity will develop. The child should feel the team's support, because it is "the very social environment where the needs, inclinations, and personality abilities are formed" [2, p. 24]. Communication of the team has a transcendental character, which is manifested in the fact that in case everyone understands the common needs and goals, they assume certain obligations when performing a common cause [2, p. 28].

Late adolescents strive for independence, but they lack determination and ability to take responsibility for their actions. $71 \%$ of students easily give up their intentions if some obstacles arise on the way towards their implementation; $35 \%$ do not dare to take the initiative when solving important cases; $39 \%$ are afraid of the situations in which they have to make their own decisions. Creating a favorable situation for the personality self-realization is possible provided that the late adolescents are able of manifesting volitional character traits. Therefore, it is necessary to develop such traits of character as determination, courage, enthusiasm, ambition, self-confidence, perseverance, firmness, persistence, self-discipline and so on.

The diagnostics showed that the students quite eagerly adopt the forms and patterns of activity (work and social) available in society. $76 \%$ of students quite easily adapt to people, ideas, and conditions. Being able to adapt in a social environment allows them to effectively adopt such forms of public communication as work, political, economic and cultural activities. $74 \%$ adhere to all the traditions of their family, providing a link between generations and, therefore, a more effective transfer of social experience within a family. $81 \%$ consider themselves to be people who respect the law, which also promotes the correct assimilation and reproduction of social activity forms, as it implies a willingness to follow formal norms.

However, $55 \%$ of those polled report that they have no conflicts with their friends if the latter failed to fulfill promises, obligations, or duties. This behavior indicates loyalty to friends, but does not increase the team's formative influence on the development of responsibility for performing their duties, so to some extent it negatively affects the assimilation of work activity patterns. It is also confirmed by the fact that $32 \%$ of the respondents do not seek to defend their opinion or decision unless it was immediately accepted by their friends. The adoption of role models is not equated with accommodation, because it is not a passive adoption of ready-made standards; it means conscious adoption of the necessary behavioral forms while taking individual characteristics into account.

Analyzing the revealed results of the social experience formation in late adolescents by activity criterion, we can emphasize that the development of late adolescents' motivation to master socially acceptable activities, adherence to norms and rules deserves special attention. Teachers' efforts should also be directed at developing students' initiative, responsibility for their actions and other strongwilled traits of character, social activity, and team interaction improvement. Late adolescents should adhere to the principles of humanity and mutual assistance, social creativity, meaningful and socially-oriented leisure, a positive attitude to various social activities in accordance with the 
available inclinations and abilities.

When developing extracurricular educational activities, it should be kept in mind that in the field of activity one observes the child's getting knowledge of the surrounding reality and his/her abilities, opportunities through the acquisition of certain actions, abilities and skills. So, the more varied the palette of practical activities is, the more attempts will be made by the child and, correspondingly, his/her experience will enrich more [8, p. 151].

Participation in various activities gives teenagers the opportunity to try and master different social roles, to gain experience of social relations, as well as of social activity; it makes for the formation and development of civic and worldview positions. As a result, the acquired social activity forces the children to participate in public life, which, as T. Alekseenko rightly points out, is an indicator of their personal development, active civic position and democratic society, which is able to listen to the children when their interests are concerned. Thus, a favorable environment for children is created and positive changes in the country take place [1, p. 42].

Based on the diagnostics results, the most appropriate organizational forms of extracurricular activity with late adolescents used to form a behavioral component of social experience are social campaigns, the issue of a wall newspaper, play production, thematic weeks, and students' research work.

Participation in social campaigns is a prerequisite for the formation of active civic position among late adolescents. The main tasks of social campaigns are development of social activity and initiative, organization of socially directed leisure of students, formation of awareness of the importance of school social activities. In addition, by participating in the school campaigns, students are given the opportunity to try themselves in different roles and tasks, to implement their own initiatives, to gain experience of social activities. In the organization of campaigns, an important role is played by the school selfgovernment as an effective force, capable of mobilizing and motivating other students to become involved.

Students' research work implies conducting miniresearch on one of the given topics and aims to broaden the students' outlook, to develop their abilities and skills of self-development, to expand students' understanding of social values, norms, traditions on the basis of research work, to develop interest in fundamental issues of human cohabitation. Possible research topics include: "Values of the people of my region", "Traditions of the peoples of the North Azov region", "Folk crafts of my region", "History of my family tree", "What do people lack for happiness?", etc. The topics are to be given in such a way that, in order to find the answers to their questions, the students should not just "get on" the Internet, but also communicate with their relatives, acquaintances, teachers, elderly people, to conduct monitoring of this question among the students of their class, visit a museum or library.

The issue of the wall newspaper aims to develop students' self-government, initiative of the whole class and individual students, to unite the school by the involvement of representatives from different classes, to form public opinion, to develop responsibility and selfdiscipline in students, to strengthen discipline, motivation to follow the behavioral norms and rules. The issue of the newspaper is possible in different formats, but we consider the wall newspaper to be the most appropriate because it does not require many resources while having the same level of positive impact on students. The subject of the newspaper may be "Our Class" or "School News", and it should be issued by representatives of different classes, which favorably influences the development of the school team. Students are given the opportunity to participate in the observation and coverage of events that are taking place or is going to take place in the class, school, and which involves collecting information through communication with people, searching the Internet, and looking for the information in the library. Students involved in making a wall newspaper develop autonomy, responsibility, social activity, organizational skills, abilities to analyze and evaluate different phenomena. However, even those who are not involved in the process of making a wall newspaper get some experience by learning about it and, accordingly, learning about the school events. Except the newspaper, it is also advisable to create other sources of information about school life, in particular, creating a page on Facebook or other social network. Information for the pages could also be provided by students. In this way, students' parents and individuals who wish to attend this school will be able to see the school events.

The most appropriate seems to be the production of the play "Rights of Children in the Modern World" [5], which aims to form students' understanding of legal norms, skills of conflict-free behaviour, to develop selfregulation skills, abilities to work in teams, selfconfidence. The choice of the play theme is due to the fact that positive social experience is enriched by building social relationships on a moral and legal basis, which includes respect for the rights of another person and the state as a whole. In addition, according to O. Vereshchak, the pleasure and enjoyment teenagers get from their perception and direct participation in musical and theatrical performances, role-playing that are close to the theatrical performance, satisfy their needs, interests, and are accompanied by emotional compassion and relaxation. It is explained by the fact that the perception of information contained in a certain art form is realized through emotional-aesthetic experience, caused by the peculiarity and specificity of the expressive means of each type of art [6, p. 33]. The staging can be performed by late adolescents for younger students.

Conducting thematic weeks contributes to the development of students' responsibility, organizational skills, their active adoption of behavioral patterns, as the students are involved in the preparation of the week. Late adolescents are able to show initiative, independence, creativity and responsibility when decorating rooms, selecting material and more.

Conclusion. Forming a behavioral component of social experience involves directing the efforts of the teaching staff to develop the following characteristics in late adolescents as: the students' awareness of their importance in the system of social production; possessing the ways of socially acceptable activities; realizing one's own individuality through participation in a common cause; affirmation in a new social position; social activity and initiative; developed strong-willed qualities - determination, ambition, self-confidence, perseverance; adaptability to 
social conditions; developed organizational skills; focus on socially meaningful leisure; developed self-regulation skills. It is possible to achieve such a result if you cooperate with students in organizing and conducting extracur- ricular activities, the variety and quality of which depends directly on the desire of teachers to help late adolescents in finding their way and self-realization in the sociocultural space.

\section{ЛИТЕРАТУРА}

1. Алєксєєнко Т. Ф. Концептуальні ідеї соціальнопедагогічного підходу у формуванні соціально-значущих якостей підростаючої особистості // Сучасний виховний процес: сутність та інноваційний потенціал: матеріали звіт. наук.-практ. конф. Ін-ту проблем виховання НАПН України за 2011 рік / [За ред. О.В. Сухомлинської, І.Д. Беха, Г.П. Пустовіта, О.В. Мельника ; літ. ред. І.П. Білоцерківець]. Івано-Франківськ: Типовіт, 2012. Вип. 2. С. $40-43$.

2. Атрошенко Т. Ю., Жмак К. В., Подпльота С. В. та ін. Виховна робота в закладах освіти: навчальний посібник / [за гол. ред. О. Г. Волкова]. Мелітополь: ФОП Однорог Т. В., 2019. $271 \mathrm{c}$.

3. Бабкіна М. I. Формування активної громадянської позиції підлітків у позакласній виховній роботі загальноосвітньої школи: автореф. дис. ... канд. пед. наук: спец. 13.00.07 ; наук. керівник Пустовіт Г. П. ; І-нТ проблем виховання АПН України. Київ, 2009. 22 с.

4. Білан Т. М. До питання набуття підлітками соціального досвіду в умовах дитячої громадської організації // Сучасний виховний процес: сутність та інноваційний поте- нціал: матеріали звіт. наук.-практ. конф. Ін-ту проблем виховання НАПН України за 2011 рік / [За ред. О.В. Сухомлинської, І.Д. Беха, Г.П. Пустовіта, О.В. Мельника ; літ. ред. І.П. Білоцерківець]. Івано-Франківськ: Типовіт, 2012. Вип. 2. С. 204-206.

5. Вацлава О. М. Сценарій вистави “Права дітей у сучасному світі”. Режим доступу: http://socialvtl.blogspot.com/2014/05/blog-post_2.html.

6. Верещак О. Позашкільна діяльність як педагогічна система та соціокультурне середовище // Рідна школа, 2006. № 12. C. $32-34$.

7. Сафронова Л. Б. Визначення стану сформованості соціального досвіду підлітків у процесі позашкільної діяльності // Теоретико-методичні проблеми виховання дітей та учнівської молоді: збірник наукових праць, 2015. Вип. 19, кн. 2. С. 214-223.

8. Якса Н.В.Формування соціального та особистісного досвіду людини як соціалізаційний процес // Креативна педагогіка. Наук.-метод. журнал / Академія міжнародного співробітництва 3 креативної педагогіки. Вінниця, 2015. Вип. 10. С. 148-153.

\section{REFERENCES}

1. Alekseenko, T. F. Conceptual ideas of the socio-pedagogical approach in the formation of socially meaningful qualities of a growing personality // Modern educational process: essence and innovative potential: proceedings of a scientific and practical conference of the Institute of upbringing problems of the NAPS of Ukraine for 2011 / [Ed. by O.V. Sukhomlynska, I.D. Bekh, H.P. Pustovit, O.V. Melnyk]. Ivano-Frankivsk: Typovit, 2012. Is. 2. P. 40-43.

2. Atroshenko, T. Yu., Zhmak, K. V., Podpliota, S. V. et al. Educational work in educational institutions: coursebook / [Ed. by O. H. Volkov]. Melitopol: FOP Odnoroh T. V., 2019. $271 \mathrm{p}$.

3. Babkina, M.I. Formation of teenagers' active civic position in extracurricular educational work at a general education school: author's thesis. Institute of upbringing problems of the APS of Ukraine. Kyiv, 2009. 22 p.

4. Bilan, T.M. Towards the issue of teenagers' acquiring social experience under the conditions of children's public organization // Modern educational process: essence and innovative potential: proceedings of a scientific and practical conference

of the Institute of upbringing problems of the NAPS of Ukraine for 2011 / [Ed. by O.V. Sukhomlynska, I.D. Bekh, H.P. Pustovit, O.V. Melnyk]. Ivano-Frankivsk: Typovit, 2012. Is. 2. P. 204-206.

5. Vatslava, O. M. Playscript "Rights of Children in the Modern World”. URL: http://social-vtl.blogspot.com/2014/05/blogpost_2.html

6. Vereshchak, O. Extracurricular activity as a pedagogical system and socio-cultural environment // Ridna shkola, 2006. № 12. P. 32-34.

7. Safronova, L. B. Defining the level of social experience formation in teenagers in the course of extracurricular work // Theoretical and methodological problems of children and students' upbringing: collection of research works, 2015. Is. 19. Book 2. P. 214-223.

8. Yaksa, N. V. Formation of social and personal experience of man as a process of socialization // Creative pedagogy. Scientific and methodological journal / Academy of international cooperation on creative pedagogy. Vinnytsia, 2015. Is. 10. P. $148-153$. 